\begin{abstract}
Iranica
Abstracta Iranica Revue bibliographique pour le domaine irano-aryen

Volume 32-33 | 2013

Comptes rendus des publications de 2009-2010
\end{abstract}

\title{
Martin Seyer. Zur Ausstattung der Kammern lykischer Felsgräber
}

\section{Astrid Nunn}

\section{OpenEdition}

1 Journals

\section{Édition électronique}

URL : http://journals.openedition.org/abstractairanica/40416

DOI : 10.4000/abstractairanica.40416

ISSN : 1961-960X

Éditeur :

CNRS (UMR 7528 Mondes iraniens et indiens), Éditions de l'IFRI

\section{Édition imprimée}

Date de publication : 1 décembre 2013

ISSN : 0240-8910

\section{Référence électronique}

Astrid Nunn, «Martin Seyer. Zur Ausstattung der Kammern lykischer Felsgräber », Abstracta Iranica [En ligne], Volume 32-33 | 2013, document 117, mis en ligne le 01 juillet 2016, consulté le 28 septembre 2020. URL : http://journals.openedition.org/abstractairanica/40416 ; DOI : https://doi.org/10.4000/ abstractairanica.40416

Ce document a été généré automatiquement le 28 septembre 2020.

Tous droits réservés 


\title{
Martin Seyer. Zur Ausstattung der Kammern lykischer Felsgräber
}

\author{
Astrid Nunn
}

\section{RÉFÉRENCE}

Martin Seyer. « Zur Ausstattung der Kammern lykischer Felsgräber ». IstMit 59, 2009, p. 51-82.

1 La Lycie est connue pour le nombre élevé de tombes rupestres. Celles-ci ont été revisitées dans le cadre du projet "Corpus der Lykischen Sprachdenkmäler» de l'Université de Vienne. Leur datation reste floue, mais elles remontent au $\mathrm{V}^{\mathrm{e}}$ et $\mathrm{IV}^{\mathrm{e}} \mathrm{s}$., donc à l'époque achéménide. L'A. a constaté un changement progressif dans l'aménagement intérieur des banquettes de pierre et des niches creusées dans le roc. Les noms des propriétaires sont lyciens.

\section{AUTEURS}

\section{ASTRID NUNN}

Université de Munich 